\title{
Geomagnetic Inclination during Last 9,000 Years Recorded in Sediment Cores from Lake Kasumigaura, Japan
}

Toshitsugu Yamazaki, Masato Joshima, and Yoshiki SAITo

Geological Survey of Japan, Tsukuba, Ibaraki, Japan

(Received July 9, 1984; Revised November 29, 1984)

\section{Introduction}

Investigation of Holocene geomagnetic secular variation using unconsolidated sediments has been made by many authors in recent years, and type curves have been constructed in North America, West Europe, Argentina and Australia (CREer et al., 1983; Creer and TuCHOLKA, 1983). In Japan, the secular variation curve for recent 2,000 years has already been established by archaeomagnetic investigations (HIROOKA, 1971; SHIBUYA, 1980), but for the period before 2,000 yr B.P., several works (YASKAWA et al., 1973; HIROOKA and TOKIEDA, 1979; HYODO and YASKAWA, 1980; INOKUCHI et al., 1981) have not yet been able to establish a reliable variation curve due to the lack of sufficient data. This paper presents a reliable record of geomagnetic inclination in Japan since 9,000 yr B.P. based on the paleomagnetism of two sediment cores from Lake Kasumigaura.

The sediment cores from Lake Kasumigaura have the following advantages for studying geomagnetic secular variation; (1) Their very high sedimentation rates ( 2 to $5 \mathrm{~mm}$ /year) enable us to get a high resolution record. The filtering effect (HYODO, 1984) caused by an acquisition of the remanence in the postdepositional burial process is considered to be very small. (2) Many interbedded volcanic ash layers are useful for the precise correlation between the two cores and their age assignments.

\section{Sampling and Measurement}

Lake Kasumigaura, of which the area is the second largest in Japan, is located about $70 \mathrm{~km}$ northeast of Tokyo (Fig. 1). Holocene sediments $50 \mathrm{~m}$ thick at maximum have filled up this lake. Its water depth is only $7.3 \mathrm{~m}$ at maximum. Core KB1 and Core KB2 were taken by modified Livingston piston sampler (AOKI and Mizuno, 1970) with core-catcher. Undisturbed cores, $28 \mathrm{~m}$ long for KB1 and $40 \mathrm{~m}$ long for $\mathrm{KB} 2$, were collected through successive 2 or 3 meter drives. The greater part of the sediments are composed of silt and clay and mostly marine in origin. Only the lowest several meters of the cores consist of brackish sand and peat in descending order. These vertical lithologic changes represent the ear- 


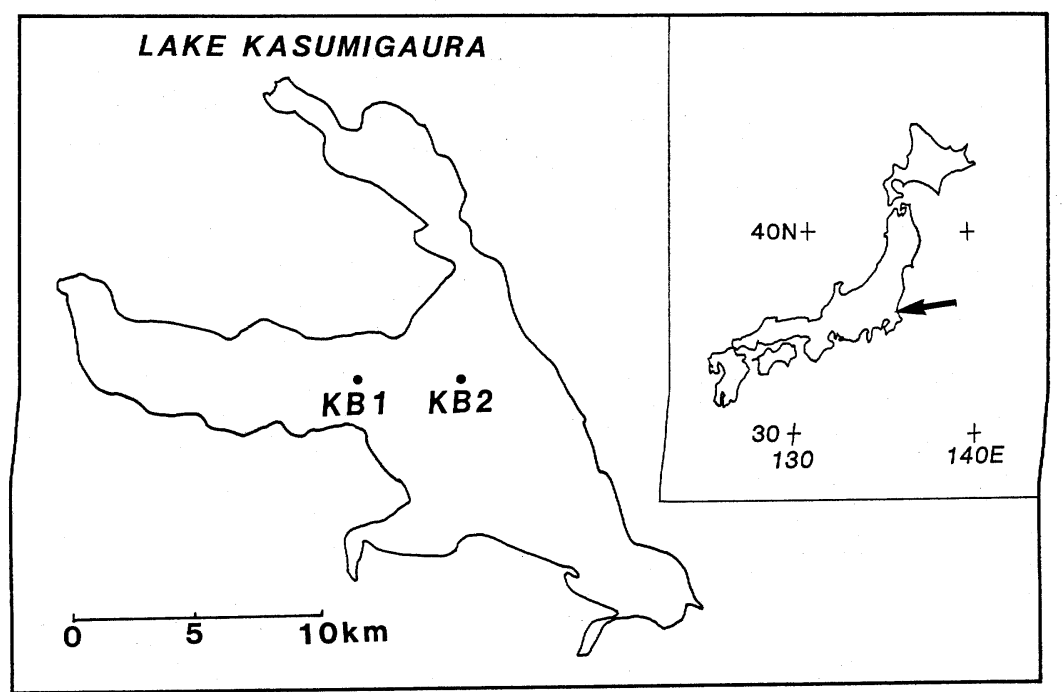

Fig. 1. Location of coring sites.

ly stage of Holocene transgression. Rates of core-recovery in silty or clayish part exceeded $95 \%$. Detailed descriptions about the coring procedure and the lithology of the cores will be presented elsewhere. Specimens for paleomagnetic measurements were taken from all part of the silts and clays in succession except for the core-catcher about $15 \mathrm{~cm}$ long in each drive by small plastic cubic case of $10 \mathrm{~cm}^{3}$. Total numbers of specimens were 950 (Core KB1) and 1,320 (Core KB2).

Natural remanent magnetization of all specimens were measured with a cryogenic rock magnetometer (SCT Model 113). The specimens selected as pilots at intervals of several meters were stepwise demagnetized in alternating field (AF) up to $20 \mathrm{mT}$. A typical example is shown in Fig. 2. Unstable components were removed by peak field of less than $5 \mathrm{mT}$. The changes in direction after each demagnetization level above $5 \mathrm{mT}$ were $2^{\circ}$ to $3^{\circ}$, and showed no systematic trend. All remaining specimens were cleaned by peak field of 5 to $10 \mathrm{mT}$. Remanent intensity after AF demagnetization ranges from $2 \times 10^{-2} \mathrm{~A} / \mathrm{m}$ to $2 \times 10^{-4}$ $\mathrm{A} / \mathrm{m}$, and it has a tendency to increase downwards along the cores without a decrease of water content of the sediments.

Unfortunately, we could not get a reliable declination record because the cores were collected in unoriented sections which were artificially twisted during their penetration. Since changes of the relative declination in each 2 or 3 meter drive are gradual and small (about $30^{\circ}$ per one meter at maximum), it can be considered that there is no effect of the core-twisting on inclination data. Therefore, only inclination data are described and discussed in this paper. 


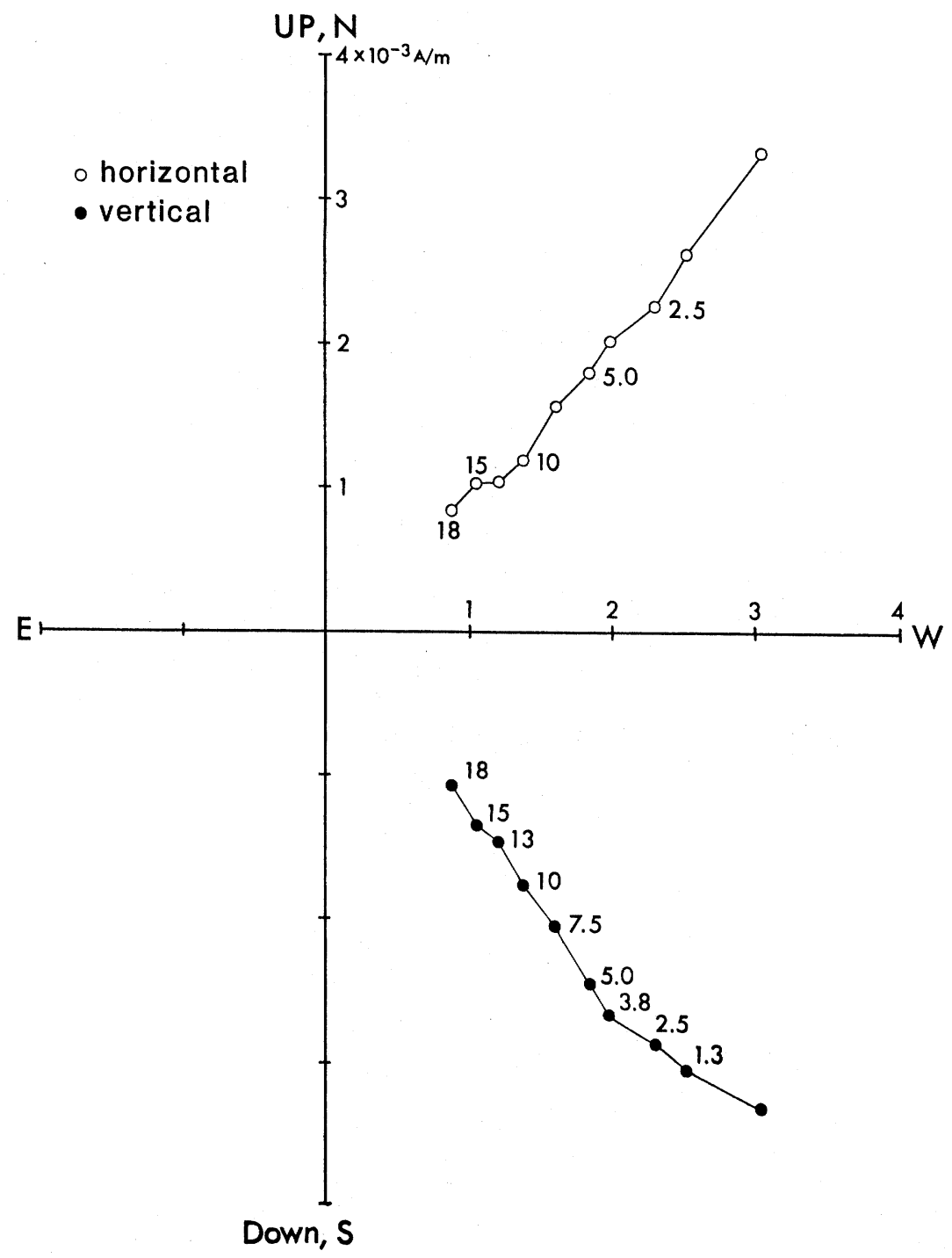

Fig. 2. Typical orthogonal vector component diagram of progressive alternating field demagnetization. Numbers adjacent to symbols are peak alternating field in $\mathrm{mT}$. Direction in horizontal plane is relative because cores are not oriented.

\section{Results and Discussion}

Inclination records of the two cores are presented in Fig. 3. The mean (cross) and the standard deviation (horizontal bar) of five specimens in vertical succes- 

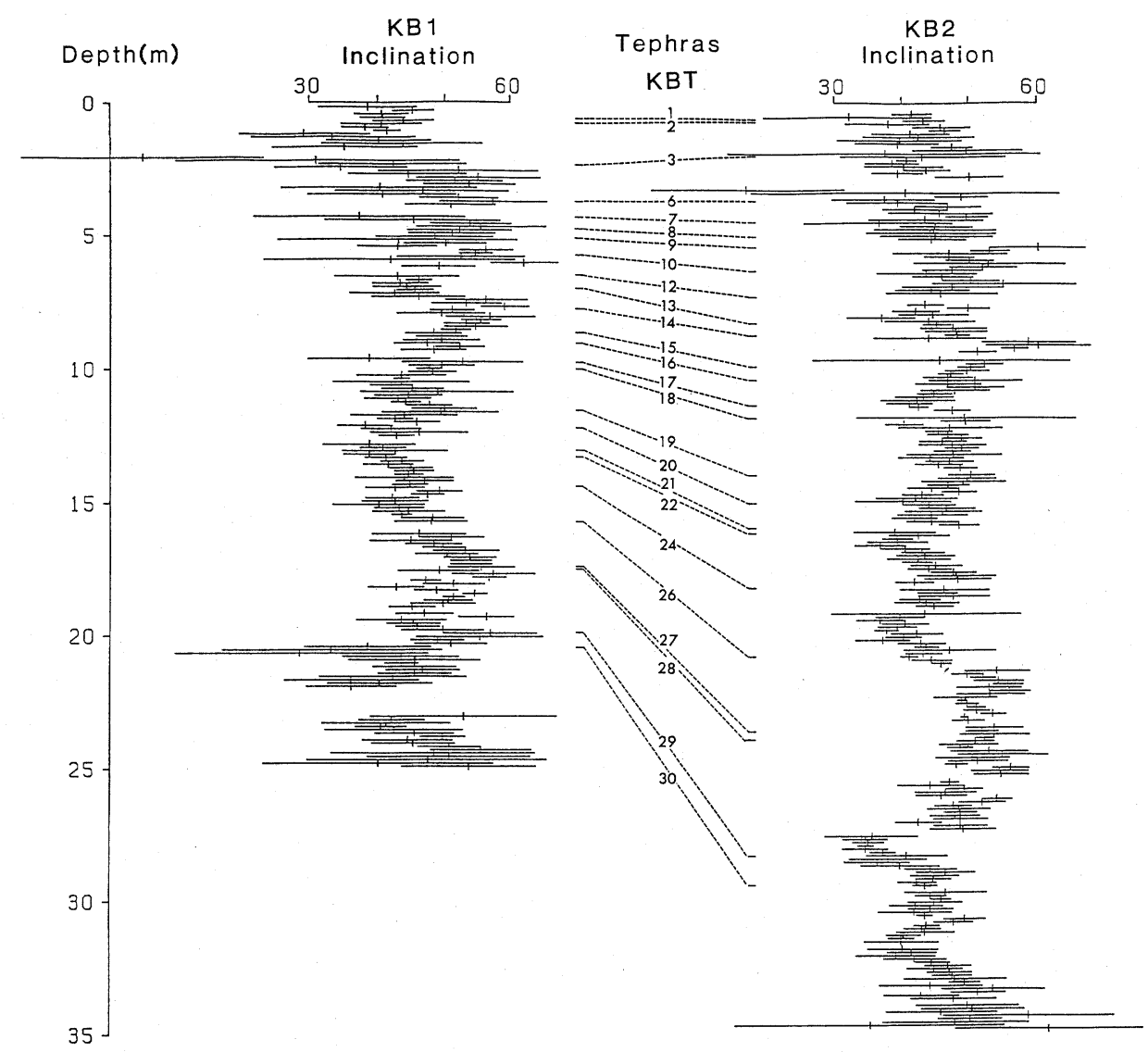

Fig. 3. Inclination records and the correlation of the two cores by tephras (KBT1-KBT30). Cross and horizontal bar represent the mean and the standard deviation of each five specimens in vertical succession. Dotted lines on the central column indicate the correspondence between two records by tephras.

sion are indicated. In Lake Kasumigaura, the sedimentation rate is so great that it takes only about 30 years (the mean of Core KB2) for accumulation of five specimens (about $13 \mathrm{~cm}$ long). We can regard these five specimens as taken from a "single horizon" because changes of the geomagnetic field for such a short period are considered to be able to be ignored here. We adopted the arithmetical mean for inclination data analysis with emphasis on simplicity and rapidness while more precise ways (MCFADDEN and REID, 1982, for example) are known. As illustrated in Fig. 3 the inclination data show fairly good convergence except for the uppermost few meters, especially those of Core KB1, where the intensity of the remanence is the weakest throughout the whole cores (less than $1 \times 10^{-3}$ $\mathrm{A} / \mathrm{m}$ ). The mean inclination of Core KB2, about $45^{\circ}$, is shallower than the in- 
clination expected from the hypothetical geocentric axial dipole field $\left(55^{\circ}\right)$ or that of the present geomagnetic field $\left(49^{\circ}\right)$. The mean of Core $\mathrm{KB} 1$ is about $50^{\circ}$ which is slightly steeper than that of Core KB2. The cause of these gaps is not clear, but according to the information that the sediments at the site of Core KB1 were softer and penetrated by the corer more easily than that of Core $\mathrm{KB} 2$, it is estimated that the compression during core-penetration may be a major reason for shallowing the observed inclination (OzIMA, 1980).

The sediments in Lake Kasumigaura are interbedded with many thin (1 to $10 \mathrm{~mm}$ in thickness) volcanic ash layers (Tephras KBT1 to KBT30 in Fig. 3). Core KB1 and Core KB2 can be correlated with each other precisely by these tephras. As shown in Fig. 3, this correlation reveals that variation of inclination with time in the two cores is almost identical with each other even for the detailed fluctuations. This result much improves the reliability of the inclination records.

Next, we transform these data into time-series. Core KB2 is selected for this purpose because Core KB2 is considered to have higher resolution than Core $\mathrm{KB} 1$ judging from its less scattered record and larger number of specimens. Some tephras are correlated with those of which ages have already been known in other domestic areas. Tephra KBT1 (0.6 m at depth in Core KB2) was identified as the Asama-A ash erupted from Mt. Asama in 1783. Tephra KBT7 $(4.5 \mathrm{~m})$ is the Yufune NO. 2 scoria (Yu-2) $(2,000$ yr B.P.) which is one of the markertephras in and around Tokyo. Tephra KBT28 $(23.9 \mathrm{~m})$ was identified as the Akahoya ash (Ah) $(6,300$ yr B.P.; MACHIDA and ARAI, 1983) which is one of the widespread marker-tephras in Japan. The age of the peat derived from the bottom of Core KB2 $(39 \mathrm{~m})$ was determined by carbon-14 method as $9,920 \pm 230$ yr B.P. (GaK-11230). We do not have any exact data either on the age or on the paleomagnetism of the sandy layer $4 \mathrm{~m}$ thick between the peat and the lowest part of the silts and clays $(35 \mathrm{~m})$. We assign, however, the age of 9,000 yr B.P. to the lowest part of the silts and clays on the assumption that the sedimentation rate is uniform between the Akahoya ash and the peat. Based on the abovementioned ages and the assumption of constant sedimentation rates through these ages, the time-series shown in Fig. 4 was constructed.

The following particular features of the secular variation of inclination can be pointed out based on the present study;

(1) Episodes of steep inclination existed from 7,000 to 6,000 yr B.P. and around 3,000 yr B.P. . A period between them is characterized by the fluctuations of small amplitude and short wavelength. The existing data (HIROOKA and TOKIEDA, 1979; HYODO and YASKAWA, 1980) do not contradict the abovementioned features.

(2) The characteristic shapes of the rounded inclination maxima and the pointed minima, which were pointed out by CREER (1983) by the data from Lake Superior, Lac de joux, and the Black Sea, are also recognized.

We wish to thank Drs. K. Oshima, Y. Inouchi and S. Yokota of Geol. Surv. Japan for sharing with us the samples and helping in the preparation of specimens for 


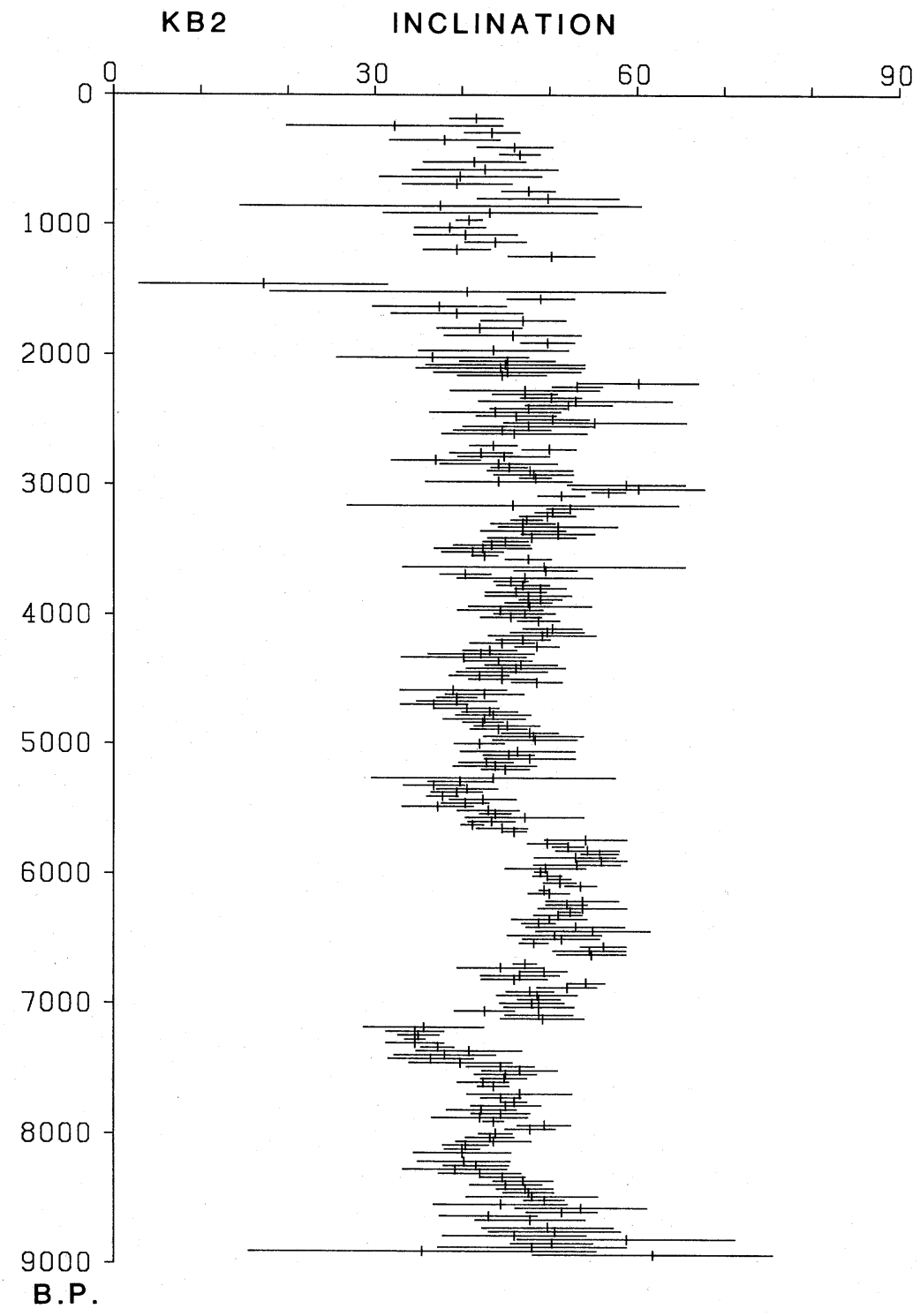

Fig. 4. Secular variation of the geomagnetic inclination recorded by Core KB2 transformed into time-series.

paleomagnetic measurements. The authors are also indebted to Dr. F. Arai of Gunma University for his identification of the Akahoya ash. This work was supported by the following two programs of Geol. Surv. Japan, the basic research for marine geophysics and the special research for surveying method of lake sediments funded by the Environ- 
ment Agency.

\section{REFERENCES}

AOKI, I. and A. MIZUNO, A piston sampler for obtaining undisturbed long core samples of Quaternary bottom deposits, J. Geol. Soc. Japan, 76, 519-523, 1970.

CREER, K. M., Computer synthesis of geomagnetic palaeosecular variations, Nature, 304, 695-699, 1983.

CREER, K. M. and P. TUCHOLKA, On the current state of lake sediment palaeomagnetic research, Geophys. J. R. Astron. Soc., 74, 223-238, 1983.

Creer, K. M., P. TUChOlKA, and C. E. BARTON, Geomagnetism of Baked Clays and Recent Sediments, 324 pp., Elsevier Science Publishers, Netherlands, 1983.

HirookA, K., Archaeomagnetic study for the past 2,000 years in Southwest Japan, Mem. Fac. Sci. Kyoto Univ., Ser. B Geol. Mineral., 38, 167-207, 1971.

HiroOKA, K. and K. TOKIEDA, Archaeomagnetic results of Sempukuji remains, the cave site, and the Holocene palaeosecular variation in Japan, Rock Magn. Paleogeophys., 6, 18-24, 1979.

HYODO, M., Possibility of reconstruction of the past geomagnetic field from homogeneous sediments, J. Geomag. Geoelectr., 36, 45-62, 1984.

HYODO, M. and K. YASKAWA, Geomagnetic secular variation recorded in the stable magnetic remanence of the young sediments collected from Osaka Bay, J. Geomag. Geoelectr., 32, 581-584, 1980.

INOKUCHI, H., H. Morinaga, and K. YASKAWA, Preliminary report on paleomagnetism of cave deposit, J. Geomag. Geoelectr., 33, 325-327, 1981.

MACHIDA, H. and F. ARAI, Widespread late Quaternary tephras in Japan with special reference to archaeology, The Quaternary Res. (Daiyonki Kenkyu), 22, 133-148, 1983.

MCFAdDEN, P. L. and A. B. REID, Analysis of palaeomagnetic inclination data, Geophys. J. R. Astron. Soc., 69, 307-319, 1982.

OzIMA, M., Effects of a plastic deformation on the remanent magnetization of a $\mathrm{Cu}-\mathrm{Co}$ alloy, Earth Planet. Sci. Lett., 47, 121-123, 1980.

SHIBUYA, H., Geomagnetic secular variation in Southwest Japan for the past 2,000 years by means of archaeomagnetism, Master Thesis of Osaka Univ., 54 pp., 1.980.

Yaskawa, K., T. Nakajima, N. KaWAi, M. ToriI, N. Natsuhara, and S. Horie, Palaeomagnetism of a core from Lake Biwa (I), J. Geomag. Geoelectr., 25, 447-474, 1973. 